Perspectivas - Portuguese Journal of Political Science and International Relations, N. ${ }^{\circ} 13$, December 2014, 31-43 (C) NICPRI 2014

\title{
Politics of Impoverishment in Nigeria from 1967 to Present: Fuel to Terrorism and National Insecurity
}

Johnmary Kelechi Ani

Samuel Ugochukwu Osisioma

Johnmary Kelechi Ani

PhD Candidat in Peace Studies in North West University,

Mafikeng, South Africa.

Lecturer, Department of History and Strategic Studies,

Federal University Ndufu-Alike, Ikwo, Ebonyi State, Nigeria

Samuel Ugochukwu Osisioma

Lecturer, Department of History and Strategic Studies,

Federal University Ndufu-Alike, Ikwo, Ebonyi State, Nigeria 


\section{ABSTRACT:}

The character of leadership in a country often influences the ship of nation building in that state. Nigeria is one country that is yet to have the blessing of transformational leadership since independence. However by 1967 when the civil war started, selfishness took-over the ambitions of the war-time leaders and by the end of the war, the country's petty-elite have become conscious of the need to manipulate poverty in order to ensure their grip of power. This work shows how the Nigerian ruling class have exploited the masses and used the army of impoverished citizenry to wage war on the state and its resources. Hence, when they disbanded each group of these armed men, they easily turned themselves into a network of kidnappers and Boko Haram activists, thereby increasing terrorism and national insecurity in the country. The work called for a change of political behaviour both on the leadership and the citizenry towards building a better as well as safe country.

\section{KEY WORDS}

Politics, Terrorism, Insecurity, Boko Haram and Poverty

\section{Introduction}

The Nigerian independence in 1960 launched the emergence of the most populous sovereign black nations on earth. However, a combination of leadership failure, ethnicity as well as the selfish ambitions of military leaders generated a false marriage with other kinds of explosive nation building factors that launched Nigeria into the civil war. However, the last straw that broke the camel's back was the quest by one group of military/ political leaders to 'steal' power and retain it at a very high and violent cost on the masses. The implication became that the country was therefore launched on the part of disintegration for years (1967-1970). As the war ravaged the sovereign state, the citizenry died in their millions and cases of near genocide was experienced in some parts of the country. Unfortunately, by the time the war ended in 1970, the leaders of the country have murdered peace as well as security and the cost of defending the sovereign political space called Nigeria and ensuring sustainable peace became a mission impossible till date. The scenario had been worsened by the fact that both the leaders and the led have tasted the inhuman gift of violence in the civil war. The military and the political leadership that have emerged at the end of the war as well as the masses have retained their war psychology for years. At the end of the war, unfortunately things shifted from the traditional scope of open bloodbath to include all forms of economic, social, political and other imaginary ways of corruption (Ani, 2014: 829-852) as well as looting in order to keep body and soul together, at a time very meagre resources are available for the crown and sceptre.

It is this selfish culture of looting by the war-time politicians and military leaders, who have graduated into our gray hair political leaders today (Ani \& Okoro, 2012: 50-58; Ani, 2012A), which led to the rise and sustenance of the politics of impoverishment that has remained in Nigeria body polity till, date. Unfortunately, it has overtime developed into a major fuel to the culture of widespread criminality, conflicts, terrorism etc. The politics of impoverishment is the process of using the machinery of the state to ensure that the larger percentages of the masses within a sovereign milieu are progressively and sometimes perpetually sentenced to life of penury. It is a system that promotes all forms of poverty, from economic poverty to intellectual and psychological poverty etc. Madunagu (2011: 9) has argued that he holds the "Nigerian's ruling classes and the Nigerian State, on the one hand and the Nigerian left, on the other hand, responsible, through acts of omission and commission, for the escalation of Nigerian terrorism. The crime of the latter (that is, the Nigerian Left) is that it could not check the 'excess' of the 
former (that is the Nigerian State and the Nigerian ruling classes) and could not absorb or could, therefore not re-channel the forces of Nigerian terrorism". It is therefore the collective failure of both the leaders and the led that have worsened the social peace of the society and permanently perverted the ethical social values in this country called Nigeria.

Africans have gone off the rail in our values and priorities, as we have become inhabitants of an imposed no-man's cultural hemisphere and because we are divorced from our basically moral and God-centred roots and are now unable to assimilate the moral and social purposes of community life, our leaders, politicians and their local and foreign business cohorts plunder the people's wealth, become wolves to man and lead the masses astray through perversity and political treachery. Hence, there are discontent and acute suffering everywhere. Strike actions and armed conflicts are rife. The ships of state are following an uncharted course; the economies are tottering; inflation is biting exceedingly hard; the few rich are becoming richer, mediocre leaders are holding the nations to ransom and the masses of African people are dismayed, disillusioned dehumanized and pauperized (Nwosu, 2000: 98-99).

The dynamics of power play and conflict in many African states have being driven by the same quest to loath as a sit-tight leader like in Cote d' Ivore (Nweke \&Ani, 2011: 32-45) or religious sentiments in Central African Republic as well as ethnic sentiments like the South Sudan experience (Ani \&Eseya, 2014: 503-510) and the Chadian case study (Ani, 2009). There is equally the growing resentment by the masses of a particular government over corruption like the Egyptian scenario (Ani, 2011A: 85-92) etc. This problem of moral recklessness is not peculiar to Nigeria as it is widespread in Africa, hence making the continent, an active theatre for the drama of war, conflicts and terrorism on world stage. But the Nigerian case seems pronounced both because of her strategic importance in the game of nations as well as the multiplier effect of her problems on the global village due to her active migrant population. Madunagu (2011: 4) wrote that "while some forms of Nigerian terrorism follow the Shakespearian maxim, 'that distribution undo excess', some others are now an integral part of the political economy and new fronts of political struggle. Nigerian 'business community' now invests in Nigerian terrorism as they invest in, say, the oil sector, in which the 'foot soldiers' in those forms and the people who actually throw the bombs or pull the trigger are like casual labourers in the old economic sector".

Ani (2011B) wrote that in order to ensure that they (politicians) must acquire power, the men and women who have been pre-selected by the political godfathers to drive 
the vehicle of politics, would join the assembly of the party or ruling oligarchy, which thinks they are "divinely ordained" to rule. This oligarchy and their political party, backed by the corrupt machinery of the state that has maintained a corrupt and non-transparent electoral empire, would ensure that those men that have received the "sacred" blessing to rule are elected in disguise to impoverish the masses.

It is the position of this paper that sustainable national security will remain elusive in the country Nigeria, not just because of the widespread cases of poverty but also because of the fact that the political class are reinforcing the culture of impoverishment on the masses. The economic marginalization of the Nigerian masses has remained a progressive political behaviour in Nigeria. It is a country where the local government development fund is integrated into the state account to allow unlimited culture of squandering. It is a country where the local government chairmen and chairladies are appointed at the mercy of the Governor, hence, if the governor coughs, they catch cold; if the governor needs any amount of money for his personal political frivolities, all of them will come together and rape their local government of the meagre resources accruing to it, in order to impress the governor. It is a country where the cold war of exploitation between the state and federal government would force the then Obasanjo administration to withhold the allocation of Lagos State under Tinubu. It is a society where the presidency could be part of the nurturing, planning and indirect sponsorship of terrorism against the number one citizen of a state, as found in the kidnapping of the then Governor of Anambra State for selfish exploitative purposes. It is a country where some of the law makers at the local government, state government and the federal bicameral arms, would at one time of the other turn the symbol of their legislative authority into a tool to break the head of their colleague, while fighting to the level of tearing their cloths and turning the legislative chambers into an animalistic gathering for wrestle mania. When they wrestle, they are not fighting for a patriotic cause, rather, they fight for the defence of 'toronto certificate', 'etegate scandal', and all forms of political frivolities that is meant to uphold the popular idea of 'share the money', which has become a fundamental bane on the Nigerian body polity. In the course of such fighting, the legislative business is murdered on the low alter of selfishness and the media while presenting a pictorial critique of their action, ironically teaches some Nigerians to adopt this ugly part of violence. Paradoxically, when some of the Nigerian political leaders invent a project to solve the problems of the masses, it ends up intensifying the hardship of the masses and leading to improved violence because of poor implementation. 
Johnmary Kelechi Ani \& Samuel Osisioma (31-43)

\section{Politics of Impoverishment and Dehumanising Capitalism}

The impoverishment of the masses is growing at an alarming rate in Nigeria due to the institutionalization of structures that promotes the broadening of the gap between the rich and the poor. The fact that riches is a product of the necessary act of hard work, does not mostly agree with the means to riches in Nigeria. In this country, some people have learnt that hardworking, day and night gives one, only the barest minimum quantity of whatever is needed to sustain the breath of the pauperized peasants as they continues a life of abject poverty. But directly before their nimble eyes, lies dozens of other people who have languished in many years of greater degree of penury, that are now financial kingmakers, they went for gunslide electoral victory which is often believed as landslide electoral victory and victory for democracy and that made all the difference. That alone moved them into the economic heart of Nigeria, where functional connection changes one's life while the greater population of the citizenry continues to languish in abject penury. It is noteworthy that political-reinforced functional connection has become the bane on Nigerian development and statecraft (Ani, 2011B).

Ani and Okoro (2012) have presented how the lack of good governance has promoted demonstration and violence in many parts of the country at different times. Unfortunately, a poor man suffers from unlimited and unimaginable level of frustration and violent psychology. It is this violent psychology that is easily unleashed on the society, whom these groups of poor people have been stretched beyond their peaceful existential threshold. Thus the relationship between poverty, violence, conflict, terrorism and other forms of insecurity are mutually re-enforcing.

It will not be an outright overstatement to say that the wind of kidnapping that turned into a cartel business in the country was driven by dehumanizing capitalism. Dehumanizing capitalism is the act of throwing the cooperate need for existential sustenance of humanity into the wind simply to ensure maximal capital gains of all forms. This is made manifest in the culture of impunity with which the protagonist and actors in the kidnap business engage in the erroneous act of exploiting and in many cases killing their victims just to sustain their flamboyant quest to belong to the petty rich class (Ani \& Nweke, 2014: 111-133; Ani, 2012B: 93-106). Unfortunately, the society in their mad praise for unevaluated wealth does not question the source of this wealth thereby increasing the pool of people who adopted the kidnapping culture as a roadmap to riches. Madunagu (2011) pointed out that kidnappings have several forms; those in which ransom is the primary 
objectives and those whose primary objective are political to blackmail, intimidate and pressure opponents. Furthermore, whereas there are organized or corporate or business-like kidnappings both for ransom and for 'politics' there are 'freelance' and individual kidnappings-the same way you have corporate supermarkets side by side with market stores and hawkers in the distributive sector of the Nigerian economy. The same applies to armed robbery, corporate and highly organized, as well as freelance and individual championed violent behaviours.

The current global economy has gone purely capitalistic. The communist society of China has even advanced their brand of communist imperialism with the dehumanizing capitalism that the state and their multi-national cooperation currently unleash on the global village. Hence, nations, individuals and groups in their quest to increase wealth under their control, build an imperial commonwealth for mass exploitation in many parts of the world. But in the African continent, the dehumanizing imperialism of sit tight leaders like Robert Mugabe as well as the widespread quest for unlimited exploitation of the masses has deepened the purgatory of poverty where many of the masses inhabit. Ani (2013B) has shown how globalization has affected the African political culture.

In Nigeria, the political class have built themselves into an oligarchy that does not only control state power but state resources. Ironically, the so-called private sector flourishes or is paralysed by the positive or negative strength of alliance between the establishment and the forces of resource control within the seat of power at both the state and federal levels. The increasing dis-empowerment of the masses through thuggery and persistent unemployment in the country forces many of the masses to think of any way to get money and survive. The implication is that these critical masses of Nigerian citizens begin to lunch their energy into more deadly violent activities following their unholy romance with the men on the seat of power.

Another manifestation of politics of impoverishment, which exhibits the character of dehumanizing capitalism, is the negative exploitation of societal resources by the political class. This they do through the award of fictitious and unmerited contracts as well as poorly implemented developmental projects. Many of the Nigerian politicians have companies and establishment that they registered with pseudo political names. These companies are not only used to bid for contracts, which abinitio, they are not qualified for but they are also given the political blessing that will help them to win such contract at very inflated cost. The inflated cost of the contract is often driven by the quest to eke-out as much 'economic flesh' from the federal, state or local economy in order to ensure adequate 'settlement' 
of all the people that supported the roadmap towards winning such a contract. When they have successfully won the contract, they practically do not execute it or in many cases do terrible jobs that raise the violent consciousness of the masses. However, in cases where the contracts are specified developmental projects for a community, the community elders and youths in some cases begin to raise eye-brows which sometimes turn out to produce different forms of insecurity from psychical insecurity to real outbreak of violence. Therefore as the gap between the rich and the poor in those communities is widening, some unemployed youths there will resort to violence in expressing their grievances. The political class in many cases have strategically failed to be fully sensitive to the plight of the masses especially in the rural areas of the country.

This dangerous culture of exploitative and dehumanizing capitalism by the politicians is a widespread culture across all the arms of Nigerian body polity. The individual masses, who watch these exploitative impunity and the wider cooperate inaction to properly punish the protagonists, soon engages in naked exploitation of other citizen as well as any institution of the state that is within their jurisdiction. The marginal effects of such exploitation include the growth in the impoverishment of the larger society as well as the increase in the violent culture and insecurity unleashed on the Nigerian state. This notion of insecurity has being expressed more in the form of new terrorism against the state and her citizenry in many parts of the country.

Madunagu (2011: 6) wrote that while the 'old terrorism' was predominantly anti-capitalist imperialism and anti-national oppression and pro-power, pro-popular democracy, pro-socialism or even pro-communism, the 'new terrorism' is anti-imperialism or anti-America or anti-West, but not anti-capitalism. The former was predominantly secular while the new terrorism is predominantly for the enthronement of Sharia. Unfortunately, the fact that terrorism everywhere, especially the Nigerian Boko Haram brand is driven by the dehumanizing quest for money has been captured by the fact that they have consistently showed that their sect is not anti-capitalistic.

In the Nigerian brand of terror economy, they rob banks and claim that the money stored there were acquired through corrupt acts. Again, the years 2011-2012 witnessed the broad day light commercial coup by the Boko Haram sect members as they would not only kill a targeted Christian shop owner in Maiduguri but will quickly loot or even take over the shop with little resistance from the masses, which were afraid of their terror attack. It took the rise of the Civilian Joint Tax force to stop that abnormally. It was these forms of criminal actions that made 
some scholars to state that the sect practised Boko Islam (Ani and Nwanaju, 2011; Nwanaju, 2010). Madunagu (2011: 9) has stated that Nigerian 'business community' now invests in Nigerian terrorism as they invest in, say, the oil sector. The terror 'foot soldiers' who throw the bombs or pull the trigger are like casual labourers in the oil sector-poorly remunerated and easily dispensable".

\section{Implications for Insecurity in Nigeria}

Chinua Achebe in his popular treatise, The Trouble with Nigeria has asserted that the problem of the people and land of Nigeria is squarely the problem of leadership failure. Consequently, widespread national insecurity which manifests in the form of robbery, kidnapping, inter-communal conflicts, terrorism etc. are an extension of the aggregate failures of our past leaders to channel the energy of millions of Nigerians that are involved in this drama of terrorism into meaningful productive ventures. Madunagu (2011: 5) has stated that he holds the "Nigeria's ruling classes and the Nigerian State, on the one hand, responsible through acts of omission and commission for the escalation of Nigerian terrorism. The crime of the latter is that it could not check the 'excesses' of the former and could not absorb and re-channel the forces of Nigerian terrorism".

It should be noted that many of the notable manifestation of insecurity in the country as found in the re-current inter-communal conflict across the length and breadth of the country as well as the commercialization of kidnapping and terrorism, reached its zenith due to the years of neglect by the state and federal governments. For instance, what emerged as the popular Niger Delta militancy was simply the manifestation of environmental struggle in the region, which the state and federal government matched with brutal naked force and the mass killings that followed it forced the members to go underground (Ani and Ohagwu, 2013). Their mastery of their underground guerrilla warfare helped them to consistently cripple the refining of crude oil. Later, they graduated into key actors in the Nigerian petro-business as well as a fully fledged kidnap booming business in many regions of the country (Ani, 2012B). It was at the apogee of their militia activities, when the national economy that is largely dependent on fuel was beginning to collapse and the counter-insurgency of the security forces continually failing in checking their activities that the federal government waked up from sleep and discovered that the environmental agitation of the people is both driven by micro-nationalism and the innate quest for equity. It was at that 
time that the country came up with the policy of amnesty, which has reasonable brought peace to the Niger Delta region.

"The incessant violent attacks in the north are functions of the economic injustice where more than 80 percent of the populace are not sure of three meals a day... the few rich flaunt their ill-gotten wealth with impunity. Go to Abuja and see the kind of structures the politicians are putting on ground. What these politicians spend on buildings is enough to set up cottage industries that would create jobs for the unemployed in their various constituencies" (Madunagu, 2011: 15). The disgruntled and disillusioned members of the society, who are angry with their lives of penury easily see the manipulation of violence as a way to exhibit their anger against the state and the people they believe were loathing their resources. That is one of the ways of understanding some of the ethno-religious attacks which is targeted at loathing the economic resources of some rich business tycoon in the north.

Similarly, the Boko Haram insurgency started a group of 'anointed political tugs' used by the then Borno State Governor, Ali Modu Sherif. He graduated them to SAS (Senator Alimodu Sherif) Super Youth and then his political 'ECOMOG' for the silencing of opposition opinion. Unfortunately, crisis started when they progressively began to dominate the machinery of the state politics to the disadvantage of the governor. Instead of trying to win them over, he started a gradual political expulsion of these his former faithful and they turned themselves into a distinct opposition voice that leaned on Islamic affiliation to win cheap popularity. Unfortunately, for the then Governor, when he wanted to raise alarm over the excesses of the sect and the mass secret killings that they have been doing in their sovereign enclave at the Railway Terminus, Maiduguri; it was too late for him to quell. The State Security Service (SSS), Christian Association of Nigeria (CAN) Borno State branch etc brought out evidence of their continuous appeal to the state and federal government to act and check the sect but they were paid deaf ear; after all, these boys were still implementing the order and political will of a godfather, whose canopy guarantees their protection.

Furthermore, the state and federal government could not proactively use their strategic advantages to co-opt some of their members and get useful information that will help in flushing them out. It was not until the Joint Security Operation in Borno State, Operation Flush killed some of their members in the preparation of the burial of their member that the Sect launched a jihad on machinery of the state in what have been referred to as the jihad of 2009 (Saliba and Ani, 2010) 
that the nation recognized that hell has been let loose on the state. Before they launched the jihad, they have sent many of their jihadists for training in bomb making and suicide bombing in Afghanistan, Pakistan, Somalia, Mauretania etc (Ani, 2013). And by the time, Borno State and Federal Government came to fight back; the sect has already raised an army of warriors from all around the Sahara and the Arab world thereby making it difficult for the security forces to conquer this battalion of men who believes that when they die and kill as many as possible, they would have attained their terror aim and maybe a better place in paradise. Today, the war against terrorism has gone beyond what counter-insurgency alone can check. While the government is promoting amnesty, counterinsurgency and other peace building initiatives, the sect is progressively frustrating many developmental initiatives that would have led to societal transformation like the continuous bombing of schools, while will keeping the society continuously uneducated and vulnerable to their dawa (preaching) of violence and terrorism.

The worst manifestation of the negative implication of this violent political culture of impoverishment is the perpetual silence of the people of good will as well as the Nigerian larger opposition elite, which include the opposition political parties, the private business giants as well as the cooperate actors in the Nigerian media industry. Madunagu (2011: 9) wrote that the primary responsibility of the Nigerian Left, a permanent and irreducible responsibility, is to pull together and 'rationalize' all sections of opposition to the present social order, this iniquitous social order, in a gigantic struggle for self-liberation. The power of the oppressors lays partly on the divisions-on whatever basis- in the ranks of the oppressed and the ability of the oppressors to mobilize sections of the oppressed in their effort to present their fights as our fight and their interests as our interests.

\section{Conclusion and Recommendations}

Madunagu (2011: 8) has stated that Nigerian terrorism and Nigerian terrorists cannot be 'flushed out' the way you flush out foreign invaders, this, for two main reasons, in the first place, the terrorists are Nigerians and in the second place, if you insist on the 'flush out' metaphor, then Nigerian terrorism cannot be flushed out without flushing out the Nigerian State and the Nigerian ruling classes as presently constituted. While some forms of Nigerian terrorism are poverty and inequality driven, some other now either constitutes integral parts of the Nigerian political economy or are new fronts of political economy or are new fronts of political struggle; intra-class and inter-class. This does not in any way mean 
that Nigerian terrorism will continue to manifest in its present form. The truth remain that as years come and go as well as governments come and go with their different manifestoes and democratic dividends; the nature of the current political struggle and national insecurity will begin to change in scope, form and dynamics.

Ani (2010) has revealed the dimensions of national insecurity in Nigeria. There are those kinds of insecurity that is driven by criminal ambitions of individuals and groups like armed robbery, kidnapping, rape, human trafficking, etc. But there are those forms of national insecurity that is unleashing an unimaginable level of negative impact on the state like ethno-religious crisis and the new wind of terrorism by the Boko Haram, the Ansaru and to a reasonable extent the Ombatse sects. The sects by all standards have unleashed all forms of onslaught to attain their new terror agenda. In their quest for this agenda, they have abandoned the limited bloodshed culture of 'old terrorism' for mass destruction of lives and properties. It would be recalled that 'old terrorism' is aimed at impressing and mobilizing the masses for clear, achievable aims, and limited bloodshed as well as collateral damages but the 'new terrorism' appear to wish to kill as many people as possible, drawing no line between 'legitimate target' and collateral damages and advertising aims that are clearly unattainable except in a world that is not inhabited by human beings. For instance, to want to impose the sharia on Nigeria or any segment of it by force of arms in 2011 is crazy (Madunagu, 2011: 7).

Again, while the military is using all forms of counterinsurgency to stop the increasing web of terror and militia groups in the country, there is equally the need for multi-dimensional peace building as well as the political will to check the widespread life of penury amongst the Nigerian people, vis-à-vis the growing gap between the rich politicians and the poor in Nigeria. Similarly, the culture of retiring or sacking the police or defence chiefs as a manifestation of the government's demonstration of their will to check national insecurity has not delivered the miraculous end to terrorism and conflicts in the country because of the widespread critical mass of factors that fuel these violent and criminal behaviours. Hence, the culture of popular call or legislative call for the removal of security chiefs as a roadmap to security is often a shot in the wrong direction, rather there should be re-shuflement that will allow for the trial of other strategic hands in the hierarchy of security chiefs. The failure of such leadership change is often driven by the fact that there is minimal limit to which direct armed confrontation can accomplish in strategically stopping all the attacks of violent clandestine groups that operate using guerrilla kinds of attack. Another reason is that proactive poli- 
cing and strategic security is a collective responsibility of everybody in the society as the security agencies can hardly deliver meaningful result without maximal cooperation with the citizenry.

Unfortunately, in Nigeria, anytime the people hear 'no cause for alarm, the situation is under control', go about your normal business, over the radio from the police spokesmen, they will immediately know that the statement is exactly the opposite and that they need to either take to their heels or be more security conscious. There is equally a wide gap between the police and the masses. The is because the citizen are largely afraid to report any security threat or breach to the police, whom they largely believe will leak the information to the enemies, which thereby turns the hunter (of the violent criminal) into the hunted (when the criminal is certainly released either by the loopholes in policing operational strategy or by the negative complexities of the Nigerian law). The army too has not been able to turn around the security gap between them and the larger society too. This is because they generally perceive and treat the other masses as bloody civilians and the so called bloody civilians prefer to live and die with their problems than to face the psychical fear and intimidation that is characteristic of civil-military relations in Nigeria. The police and the army hierarchy need to work hard to change the official behaviour of their men and women to promote the culture of collective responsibility for peace and security amongst the masses and security officials.

\section{References}

Ani, Kelechi Johnmary (2014) "Corruption, Social Violence and Ethical Culture in Nigeria", Independent Journal of Management and Production, Vol. 5, No. 1. pp. 829-852.

- (2013) "Foreign Influence on the Nigerian Terror Group", Africana Studies Review, Vol. 3 , No. 3 pp. $130-144 \ldots$

- (2013B) "Globalisation and its Impact on the African Political Culture", World Affairs: The Journal of International Issues, Vol. 17, Issue 2, India, pp. 44-61.

- (2012A) "Political Violence in Nigeria and Peaceful Political Communication for Sustainable National Democracy", in D. Wilson (Ed.) The Media, Terrorism \& Political Communication in Nigeria, Uyo: BSM Resources Ltd, pp. 140-158.

- (2012B) “Kidnapping and Children's Plight in Nigerian Nation Building Process", Lapai Journal of Humanities, Vol. 6, No. 1, pp 93-106.

- (2011A) "Revolution in Egypt: The Influence of Satellite Televisions", Global Journal of Applied, Management and Social Sciences, Vol. 2, pp. 85-92. 
- (2011B) Politics about Failed State in Nigeria: Dialectics on Value of History to Nation Building Challenges 1960-2010, Enugu: FirstBook.

- (2010) "Issues and Challenges of National Security to Human Capital Development in Nigeria", Lit Academic Journal: An International Multi-Disciplinary Publication, Vol. 1, No 2, pp 155-163.

- (2009) "A Study of Nigerian Peace Efforts in Chad", Maiduguri Journal of Peace, Diplomatic and Development Studies, Vol. 2, No. 1, January - June, pp. 79-83.

Ani, K. J. And Eshaya, G. (2014) "South Sudan Conflict: The Need for Transitional Justice and Strategic Peace Building", Proceedings of SOCIOINT14 -International Conference on Social Science and Humanity, Istanbul, Turkey, $8^{\text {th }}-10^{\text {th }}$ September, 2014 pp. 503-510.

Ani, Kelechi Johnmary and Nwanaju, Isidore (2011) "Boko Haram Onslaught in Nigeria: Implications on the Igbo". A Paper Presented at the Maiden South-East History Summit by the Historical Society of Nigeria (HSN), South-East Zone in Ebonyi State University, Abakaliki from $11^{\text {th }}-14^{\text {th }}$ September

Ani, K. J. and Nweke, E. (2014) "Curbing Kidnapping in Nigeria: An Exploration of Strategic Peace Building Tool", Africa's Public Service Delivery and Performance Review, Vol. 2, Issue 1, March, pp. 111-133.

Ani, Kelechi Johnmary and Ohagwu, Ijeoma Genevieve (2013) “Niger-Delta People: Origins, Environmental Crisis and Peace Building Strategies" in P. U. Omeje and U. U. Okonkwo (Eds.) New Perspectives on West African History: Festchrift in Honour of Prof. S. C. Ukpabi, Enugu: Madonna University Press, pp. 149-172.

Ani, Kelechi Johnmary and Okoro, Sylvanus I. (2012) "Contemporary Demonstrations, Violence and the Challenge of Good Governance in Nigeria" in A. B. C. Chiegboka, T. C. Utoh-Ezeajugh, E. U. Ibekwe, C. C. Nwosu, N. C. Oguno, K. L. Nwadialor (Eds.) The Humanities and Good Governance, Nimo: Rex Charles \& Patrick Ltd, pp. 50-58.

Dada, Joel Patrick and Ani, Kelechi Johnmary (2010) "The Impact of Terrorism on Nigerian National Image" in Dada, J. P., Abdulmumini, S. \& Abubakar, M. (Eds.) Peace, Security, Human Rights and Development in the $21^{\text {st }}$ Century, Vol. II. Kaduna: Pyla-Mak Services Ltd. pp. 317-333.

Madunagu, Edwin (2011) "Reflections on Nigerian Terrorism", The Constitution: A Journal of Constitutional Development, Vol 11, No. 4, December, pp. 1-16.

Nwanaju, Isidore U. (2010) "Boko Haram: Neither Islamic nor Religious", in Simon O. Anyanwu and Isidore Nwanaju (Eds.) Boko Haram: Religious Conflicts and Dialogue Initiatives in Nigeria Vol. 1, Owerri: Edu-Edy Publishers, pp. 106-107.

Nweke, Eugene N. and Ani, K. J. (2011) “Peace Building in Post-Conflict Cote D' Ivore: Can Transitional Justice and Forgiveness Make any Difference", EBSU Journal of Social Sciences, Vol. 1, No. 2, pp. 32-45.

Nwosu, Emmanuel J. (2000) The Challenge of Poverty in Africa, Owerri: Skillmark Media Ltd.

Saliba, B. James and Ani, Kelechi Johnmary (2010) "The Influence of Yusufiya Sect on Social Movement in Nigeria". A Paper Presented at the $5^{\text {th }}$ Annual Congress of Historical Society of Nigeria, Nasarawa State University, Keffi, $8^{\text {th }}-10^{\text {th }}$ March. 